\title{
Nataxazole, a New Benzoxazole Derivative with Antitumor Activity Produced by Streptomyces sp. Tü 6176 ${ }^{\dagger}$
}

\author{
Patricia S. M. Sommer, Rosemary C. Almeida, Kathrin Schneider, Winfried Beil, \\ Roderich D. Süssmuth, Hans-Peter Fiedler
}

Received: July 25, 2008 / Accepted: November 4, 2008

(C) Japan Antibiotics Research Association

\begin{abstract}
The new benzoxazole derivative nataxazole was isolated from Streptomyces sp. (strain Tü 6176). Nataxazole is related in structure to the potent antitumor compounds UK-1 and AJI9561 and showed similar strong growth inhibitory activity against various human tumor cell lines.
\end{abstract}

Keywords benzoxazole derivative, HPLC-diode array screening, antitumor activity, structure elucidation, Streptomyces

Freshly isolated actinomycetes from soils collected in the environment of Natal, Rio Grande do Norte, Brasil, were grown in submerged culture in different media, and extracts prepared from mycelia and culture filtrates at various fermentation times were screened by HPLC-diode array analysis in combination with an in-house developed HPLCUV-Vis database [2] to detect novel secondary metabolites. Strain Tü 6176 was found to be of special interest as it gave a mycelium extract that contained a dominant peak in the HPLC profile with a retention time of 14.8 minutes in standard reversed-phase gradient elution [2]. Its

H.-P. Fiedler (Corresponding author): Mikrobiologisches Institut, Universität Tübingen, Auf der Morgenstelle 28, 72076 Tübingen, Germany, E-mail: hans-peter.fiedler@uni-tuebingen.de

P. S. M. Sommer, R. C. Almeida: Centro de Biociencias, Universidade Federal do Rio Grande do Norte, Natal 59078-970, RN, Brasil

W. Beil: Institut für Pharmakologie, Medizinische Hochschule Hannover, 30625 Hannover, Germany characteristic UV-visible spectrum (Fig. 1) differed from that of 867 reference compounds stored in the HPLC-UVVis database. Due to the collection site and its chemical structure (Fig. 2), the compound was named nataxazole (1).

Strain Tü 6176 (RN-13.5) was isolated from a soil sample collected at Mata da Estrela, RN, Brazil. It was examined for a number of key properties known to be of value in streptomycete systematics. The presence of LLdiaminopimelic acid in the peptidoglycan [3] together with

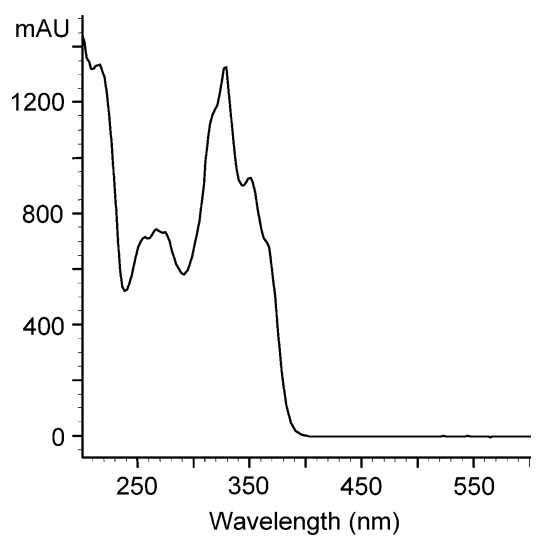

Fig. 1 UV-visible spectrum of nataxazole (1).

R. D. Süssmuth (Corresponding author), K. Schneider: Institut für Chemie, FG Organische Chemie, Technische Universität Berlin, Straße des 17. Juni 124, 10623 Berlin, Germany, E-mail: suessmuth@chem.tu-berlin.de

†Art. No. 47 in 'Biosynthetic Capacities of Actinomycetes'. Art. No. 46: see ref. 1 


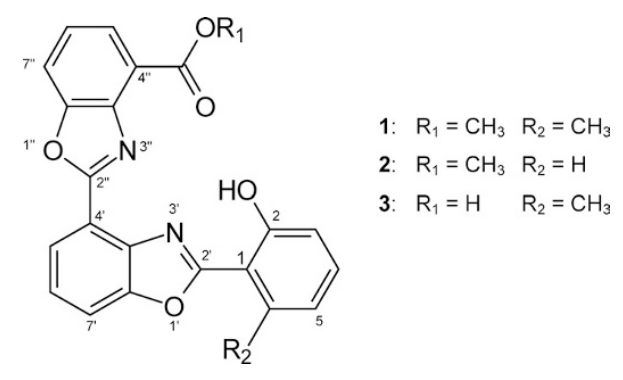

Fig. 2 Structures of nataxazole (1), UK-1 (2) and AJI9561 (3).

its colonial characteristics [4] allowed its assignment to the genus Streptomyces. Partial sequencing of the 16S rRNA gene led to a similarity of $97.6 \%$ with Streptomyces coelicolor DSM 40144.

Batch fermentations of strain Tü 6176 were carried out in a 20-liter fermentor equipped with a turbine impellor system (b20; Giovanola) in a medium that consisted of mannitol $20 \mathrm{~g}$ and soybean meal $20 \mathrm{~g}$ in 1 liter tap water $(\mathrm{pH} 7.5)$. The fermentor was inoculated with $5.0 \%$ by volume of a shake flask culture grown at $27^{\circ} \mathrm{C}$ in $500 \mathrm{ml}-$ Erlenmeyer flasks with one baffle for 48 hours on a rotary shaker at $120 \mathrm{rpm}$. The fermentation was carried out for 5 days with an aeration rate of $0.5 \mathrm{vvm}$ and agitation at $1,000 \mathrm{rpm}$. The production of 1 started at about 48 hours when the culture reached a biomass of 21 vol- $\%$, leading to a maximal nataxazole yield of $40 \mathrm{mg} /$ liter at 72 hours of fermentation. 1 was isolated from the mycelium by extraction with $\mathrm{MeOH}$. After concentration to an aqueous residue nataxazole was re-extracted by EtOAC and separated by subsequent column chromatography on Sephadex LH-20 and Toyopearl HW-40 (each column $2.5 \times 90 \mathrm{~cm}$, flow rate $30 \mathrm{ml} /$ hour) using $\mathrm{MeOH}-\mathrm{CH}_{2} \mathrm{Cl}_{2}$ $(2+1)$ as eluent. After concentration in vacuo to dryness, 1 was obtained as a pale yellow powder in a quantity of $142 \mathrm{mg}$.

The mass spectrum derived from HPLC-ESI-MS chromatograms revealed the molecular mass for 1 [ $(\mathrm{M}+$ $\left.\mathrm{H})^{+}=401.0\right]$. The exact molecular mass was determined by high-resolution ESI-FT-ICR-MS as 401.11329 Da $\left[(\mathrm{M}+\mathrm{H})^{+}\right](\mathbf{1})$, corresponding to the molecular formula $\mathrm{C}_{23} \mathrm{H}_{16} \mathrm{~N}_{2} \mathrm{O}_{5}(\mathbf{1})\left[(\mathrm{M}+\mathrm{H})^{+}{ }_{\text {theor }}=401.11320 ; \Delta \mathrm{m}=0.22 \mathrm{ppm}\right]$. The ${ }^{1} \mathrm{H}$-NMR-spectrum of $\mathbf{1}$ showed nine signals in the aromatic region, six duplets and three triplets, and two single methyl signals in the aliphatic region (Table 1). One proton was missing in the ${ }^{1} \mathrm{H}-\mathrm{NMR}$ spectrum suggesting the presence of a hydroxyl group. ${ }^{13} \mathrm{C}-\mathrm{NMR}$ and DEPT spectra revealed the presence of two methyl groups, nine aromatic $\mathrm{CH}$ groups and eleven $s p^{2}$ quaternary carbons. At
Table $1{ }^{1} \mathrm{H}$ - and ${ }^{13} \mathrm{C}-\mathrm{NMR}$ spectral data of nataxazole (1) in $\mathrm{CD}_{2} \mathrm{Cl}_{2}$

\begin{tabular}{|c|c|c|}
\hline \multirow{2}{*}{ No. } & \multicolumn{2}{|c|}{1} \\
\hline & $\delta\left({ }^{1} \mathrm{H}\right)[p p m] \mathrm{J}$ in $\mathrm{Hz}$ & $\delta\left({ }^{13} \mathrm{C}\right)[\mathrm{ppm}]$ \\
\hline 1 & - & 109.9 \\
\hline 2 & - & 161.8 \\
\hline 3 & $7.03 \mathrm{~d}(8.1)$ & 116.2 \\
\hline 4 & 7.36 t (7.9) & 133.8 \\
\hline 5 & $6.87 \mathrm{~d}(7.1)$ & 123.1 \\
\hline 6 & - & 140.0 \\
\hline $2^{\prime}$ & - & 166.6 \\
\hline $3^{\prime} a$ & - & 137.8 \\
\hline $4^{\prime}$ & - & 117.9 \\
\hline $5^{\prime}$ & $8.35 d(7.3)$ & 125.7 \\
\hline $6^{\prime}$ & 7.58 t (8.0) & 125.8 \\
\hline $7^{\prime}$ & $7.86 \mathrm{~d}(7.5)$ & 114.5 \\
\hline 7'a & - & 150.5 \\
\hline $2^{\prime \prime}$ & - & 162.2 \\
\hline 3"a & - & 142.2 \\
\hline $4^{\prime \prime}$ & - & 123.1 \\
\hline $5^{\prime \prime}$ & $8.07 \mathrm{~d}(7.7)$ & 127.8 \\
\hline $6^{\prime \prime}$ & $7.50 \mathrm{~d}(7.9)$ & 125.5 \\
\hline $7^{\prime \prime}$ & $7.89 \mathrm{~d}(8.1)$ & 115.5 \\
\hline 7"a & - & 151.9 \\
\hline $\mathrm{Me}$ & $2.87 \mathrm{~s}$ & 23.6 \\
\hline coOMe & - & 166.4 \\
\hline cooMe & $4.14 \mathrm{~s}$ & 52.9 \\
\hline
\end{tabular}

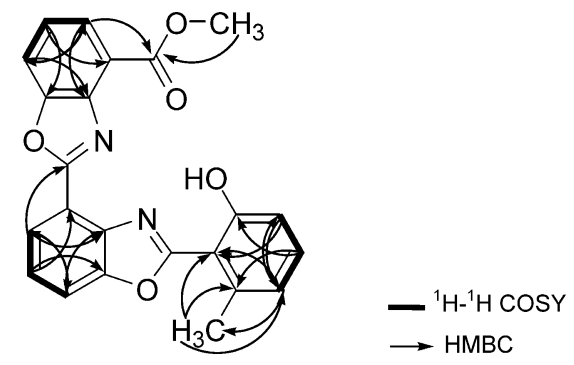

Fig. 3 Selected 2D NMR correlations for nataxazole (1).

first glance one quaternary $\mathrm{C}$-atom was missing, but with the help of the HMBC experiment it became clear that the chemical shift of this quaternary C-atom (C-4") was identical with the chemical shift of C-5. The structure was fully elucidated using COSY and HMBC spectra. The ${ }^{1} \mathrm{H}-$ ${ }^{1} \mathrm{H}$-COSY experiment revealed three spin systems, showing correlations from $\mathrm{H}-3$ to $\mathrm{H}-5$, from $\mathrm{H}-5^{\prime}$ to $\mathrm{H}-7^{\prime}$ and from $\mathrm{H}-5^{\prime \prime}$ to H-7" (Fig. 3). The structure was fully elucidated using the HMBC spectrum. The correlations from $\mathrm{H}-3$ to 
Table 2 Growth inhibitory activity $(\mu \mathrm{g} / \mathrm{ml})$ of nataxazole (1) and UK-1 (2) against selected human tumor cell lines

\begin{tabular}{lllllll}
\hline & \multicolumn{3}{c}{$\mathbf{1}$} & & \multicolumn{2}{c}{$\mathbf{2}$} \\
\cline { 2 - 3 } \cline { 5 - 6 } Cell line & $\mathrm{GI}_{50}$ & TGI & & $\mathrm{GI}_{50}$ & TGI \\
& & & & & & \\
\hline AGS & 0.4 & 2.5 & & 0.8 & 1.9 \\
MCF7 & 0.68 & 1.7 & & 0.65 & 2.4 \\
HepG2 & 0.06 & 0.4 & & 0.085 & 3.5 \\
\hline
\end{tabular}

$\mathrm{GI}_{50}: 50 \%$ growth inhibition; TGI: $100 \%$ growth inhibition.

C-1 and C-5, from H-4 to C-2 and C-6, from H-5 to C-1, C3 and to the methyl group, from $\mathrm{H}-5^{\prime}$ to $\mathrm{C}-2^{\prime \prime}, \mathrm{C}-3^{\prime}$ a and $\mathrm{C}-$ 7', from $\mathrm{H}-6^{\prime}$ to $\mathrm{C}-4^{\prime}$ and $\mathrm{C}-7^{\prime} \mathrm{a}$ and from $\mathrm{H}-7^{\prime}$ to $\mathrm{C}-3^{\prime} \mathrm{a}$ and $\mathrm{C}-5^{\prime}$, from $\mathrm{H}-5^{\prime \prime}$ to $\mathrm{C}-3^{\prime \prime} \mathrm{a}, \mathrm{C}-7^{\prime \prime}$, and COOMe, from $\mathrm{H}-$ 6" to C-4" and C-7"a and from H-7" to C-3"a and C-5", shown in Fig. 3, gave proof for the structure of nataxazole.

As shown in Fig. 2, nataxazole (1) is related in structure to the benzoxazole compounds UK-1 (2) [5] and AJI 9561 (3) [6]. Both 2 and $\mathbf{3}$ exhibit a high cytotoxic activity against mouse leukemia (P388) cells. Furthermore, 2 is reported to have potent activity against melanoma cells (B16), human epitheloid carcinoma cells and against solid tumor-derived cell lines.

The inhibitory action of nataxazole (1) on the growth of tumor cells was compared with UK-1 (2) and tested according to NCI guidelines [7] with the human tumor cell lines AGS (gastric adenocarcinoma), MCF7 (breast adenocarcinoma) and HepG2 (hepatocellular carcinoma). The cells were cultivated in 96-well microtiter plates in RPMI 1640 with $10 \%$ fetal calf serum in a humidified atmosphere of $5 \% \mathrm{CO}_{2}$ in air. After 24 hours $\mathbf{1}$ and $\mathbf{2}$ $(0.01 \sim 10 \mu \mathrm{g} / \mathrm{ml})$ were added to the cells and the cells cultivated for additional 48 hours. The cell count was surveyed by protein determination with sulforhodamine B. From the resulting concentration-activity curves, the $\mathrm{GI}_{50}$ (concentration at which half of the cells were inhibited in their growth) and TGI values (concentration at which a total inhibition of cell growth was observed) were obtained. The cytotoxic activity of $\mathbf{1}$ is somewhat better than UK-1 against AGS cells $\left(\mathrm{GI}_{50} 0.4 \mu \mathrm{g} / \mathrm{ml} v s .0 .8 \mu \mathrm{g} / \mathrm{ml}\right.$ for UK-1) and equal against MCF7 and HepG2 cells (Table 2). UK-1 binds to double-stranded DNA in a metal ion-dependent fashion. One consequence of this interaction is inhibition of topoisomerase II [8]. Topoisomerase inhibitors arrest cells in $\mathrm{S}$ or $\mathrm{G} 2$ phase depending on time or concentration [9]. Cell cycle distributions were determined in AGS cells by staining DNA with propidium iodide. AGS cells were incubated for 24 hours with $0.5 \mu \mathrm{g} / \mathrm{ml} 1$ and 2, harvested by
Table 3 Cell cycle analysis of AGS cells exposed to nataxazole (1) and UK-1 (2), respectively, for 24 hours

\begin{tabular}{lrrrr}
\hline & $\begin{array}{c}\text { Sub G1 } \\
\text { (apoptosis) }\end{array}$ & G0/G1 & S & G2/M \\
\hline $\mathbf{1}(0.5 \mu \mathrm{g} / \mathrm{ml})$ & $8.3 \pm 0.3^{*}$ & $43 \pm 3.5$ & $37.6 \pm 2.4^{*}$ & $11.4 \pm 1.6^{*}$ \\
Control & $2.9 \pm 0.7$ & $52.4 \pm 2.1$ & $23.5 \pm 1.7$ & $21.3 \pm 2.2$ \\
\hline $\mathbf{2}(0.5 \mu \mathrm{g} / \mathrm{ml})$ & $3.7 \pm 0.8$ & $58.0 \pm 6.0$ & $24.1 \pm 1.0^{*}$ & $13.5 \pm 0.4^{*}$ \\
Control & $2.1 \pm 0.3$ & $56.3 \pm 1.5$ & $18.5 \pm 0.6$ & $24.1 \pm 1.9$ \\
\hline
\end{tabular}

Data represent percentage of cells in each stage of the cell cycle. Values are means $\pm S$.E. of three independent experiments.

${ }^{*} p<0.05$ versus appropriate control ( $t$-test).

trypsination and resuspended in $100 \mu \mathrm{l}$ staining solution (150 $\mu \mathrm{g} / \mathrm{ml}$ propidium iodide, $4.0 \mathrm{mM} \mathrm{Na-citrate} \mathrm{pH} 7.0$, $1.0 \%$ Triton $\mathrm{X}-100,1.0 \%$ BSA). After 15 minutes incubation at room temperature in the dark, $100 \mu$ RNAse solution $(10 \mathrm{mg} / \mathrm{ml}$ ribonuclease $\mathrm{A}$ in Tris- $\mathrm{HCl}$ buffer $\mathrm{pH}$ 7.5) were added. Thirty minutes later cells were analyzed using a Becton Dickinson FACSscan.

The cell-cycle analysis revealed that nataxazole (1) and UK-1 (2) produce an accumulation of cells in S phase and reduce the ratio of cells in the G2/M phase (Table 3). These findings indicate that $\mathbf{1}$ and $\mathbf{2}$ may excert their inhibitory effect on cell growth by a similar mechanism of action.

No antibacterial and antifungal activity of $\mathbf{1}$ was observed against Gram-positive and Gram-negative bacteria, yeasts and filamentous fungi, respectively.

\section{References}

1. Fiedler H-P, Dieter A, Gulder TAM, Kajahn I, Hamm A, Brown R, Jones AL, Goodfellow M, Müller WEG, Bringmann G. Genoketides A1 and A2, new octaketides and biosynthetic intermediates of chrysophanol produced by Streptomyces sp. AK 671. J Antibiot 61: 464-473 (2008)

2. Fiedler H-P. Biosynthetic capacities of actinomycetes. 1. Screening for secondary metabolites by HPLC and UVVisible absorbance spectral libraries. Nat Prod Lett 2: 119-128 (1993)

3. Staneck JL, Roberts GD. Simplified approach to the identification of aerobic actinomycetes by thin layer chromatography. Appl Microbiol 28: 226-231 (1974)

4. Williams ST, Goodfellow M, Alderson G. Genus Streptomyces Waksman and Henrici 1943, 339 $9^{\mathrm{AL}}$. In Bergey's Manual of Systematic Bacteriology, Vol. 4. Ed., Williams ST et al., pp. 2452-2492, Williams \& Wilkins, Baltimore (1989)

5. Ueki M, Shibata K, Taniguchi M. UK-1, a novel cytotoxic 
metabolite from Streptomyces sp. 517-02. IV. Antifungal action of methyl UK-1. J Antibiot 46: 1089-1094 (1998)

6. Sato S, Kajiura T, Noguchi M, Takehana K, Kobayashi T, Tsuji T. AJI9561, a new cytotoxic benzoxazole derivative produced by Streptomyces sp. J Antibiot 54: 102-104 (2001)

7. Grever MR, Shepartz SA, Chabner BA. The National Cancer Institute: cancer drug discovery and development program. Semin Oncol 19: 622-638 (1992)
8. Reynolds MB, DeLuca MR, Kerwin SM. The novel bis(benzoxazole) cytotoxic natural product UK-1 is a magnesium ion-dependent DNA binding agent and inhibitor of human topoisomerase II. Bioorg Chem 27: 326-337 (1999)

9. Kaufmann WK. Human topoisomerase II function, tyrosine phosphorylation and cell cycle checkpoints. Proc Soc Exp Biol Med 217: 327-334 (1998) 